\title{
Coliformes no rio São Manoel (MG) durante o período chuvoso
}

As bactérias do grupo coliformes são consideradas indicadores de contaminação fecal. Em decorrência disso, este estudo teve por objetivo avaliar a qualidade da água do rio São Manoel (MG) ao longo dos $37 \mathrm{Km}$ de extensão, foram monitorados cinco locais entre setembro 2015 e março 2016. Os parâmetros observados foram coliformes totais, coliformes fecais, oxigênio dissolvido e vazão. Os coliformes foram detectados em triplicata por meio de cartelas em meio de cultura em forma de gel desidratado (dipslide de papel - Tecnobac Colipaper ${ }^{\circledR}$ ). A ANOVA de duas vias (Bonferroni) demostrou que houve diferença altamente significativa $(p<0,0001)$ com interação $(p<0,05)$ entre os fatores: local de coleta e tempo, para contaminação bacteriana (Log). A água a montante do rio encontrava-se em boas condições, porém, ao longo de sua trajetória, a qualidade foi degradada até desembocar no rio Pomba. Esta poluição é característica de esgoto não tratado e tornou a água inapropriada ao consumo animal e humano. Portanto, para solucionar esta situação, é necessária a aplicação de medidas de saneamento básico.

Palavras-chave: Água; Coliformes Termotolerantes e Totais; Oxigênio Dissolvido; Poluição.

\section{Coliforms in São Manoel river (MG) during the rainy period}

\begin{abstract}
Coliform bacteria group serves as indicator of faecal contamination. As a result, this study aimed to evaluate the water quality of the river São Manoel ( MG ) along its 37 km, had five locations monitored between September 2015 and March 2016. The observed parameters were: total coliforms, fecal coliforms, dissolved oxygen and water volume flow. The coliforms were detected in triplicate using cards with culture medium in the form of dehydrated gel (DIPSLIDE paper - Tecnobac Colipaper ${ }^{\circledR}$ ). The two-way ANOVA (Bonferroni) demonstrated that there was a highly significant difference $(p$-value $<0.0001)$ with interaction $(p$-value $<0.05)$ between the factors local of collection and time for the bacterial contamination (Log). The water from the beginning of the river has good condition, however, throughout its flow, the quality degrades until it discharges into the Pomba river. This pollution is characteristic of untreated sewage, so the water becomes unsuitable for animal and human consumption. These situation can be solved by the application of basic sanitation measures.
\end{abstract}

Keywords: Water; Total and Faecal Coliforms; Dissolved Oxygen; Pollution.

Topic: Engenharia de Recursos Hídricos

Reviewed anonymously in the process of blind peer
Received: 11/02/2017

Approved: 21/04/2017
João Batista Martins

Universidade Brasil, Brasil

http://lattes.cnpq.br/4402297019434984

joao.martins@ifsudestemg.edu.br

Silvio Leite Monteiro da Silva

Universidade Paulista, Brasil

http://lattes.cnpq.br/7074777836288684

silvio.leite@ifsudestemg.edu.br
6

DOI: 10.6008/SPC2179-6858.2017.003.0008
Referencing this:

MARTINS, J. B.; SILVA, L. M. S.; ANDREANI, D. I. K.. Coliformes no rio São Manoel (MG) durante o período chuvoso. Revista IberoAmericana de Ciências Ambientais, v.8, n.3, p.78-87, 2017. DOI: http://doi.org/10.6008/SPC2179-6858.2017.003.0008 


\section{INTRODUÇÃO}

O mundo passa por momentos preocupantes, em relação ao fornecimento de água em quantidade e qualidade suficientes para os mais variados fins. No entanto, grande parte das bacias hidrográficas está degrada e contaminada. A preservação da qualidade da água deve ser encarada como uma necessidade universal que exige atenção especial dos governantes, autoridades sanitárias e consumidores em geral. Tendo em vista a importância da água para a vida e a partir dos relatos dos problemas causados pela contaminação da água, torna-se imprescindível conhecer a situação atual de qualquer bacia hidrográfica. Um dos caminhos é monitorar a qualidade da água por meio de analises.

A atual política nacional de recursos hídricos, estabelecida na Lei Federal $n^{\circ} 9.433 / 1997$, considera a água um bem público, dotado de valor econômico, cujo uso prioritário é o consumo humano. Assim as alternativas de integração do uso da água com as diversas atividades econômicas e sociais que atendem aos mais diversos interesses, tornam-se cada vez mais direcionadas à conservação (PARADELA, 2006).

Devido ao papel importante que a água desempenha na vida animal e humana, desde a antiguidade as grandes cidades e civilizações se desenvolveram às margens dos rios. Nesse sentido, a água assume caráter imprescindível para a sobrevivência dos povos. Entretanto, da mesma forma que a sua presença cria condições para a vida, a má qualidade da água pode, também, representar sérios riscos à saúde ao transportar microrganismos patogênicos e substâncias tóxicas (SILVEIRA, 2007).

A intensa urbanização, o aumento da demanda por água doce, a elevada quantidade de lançamento de efluentes sem tratamento, o uso indiscriminado dos recursos hídricos para fins agrícolas, industriais e domésticos, a consequente contaminação da água são considerados os maiores problemas a serem enfrentados neste século (TUCCl, 2008). A água é uma preocupação mundial, e à medida que a humanidade cresce, há aumento de aglomerações urbanas, ocorre uma degradação da sua qualidade e modificação de sua composição natural, gerada pelo despejo de poluentes, pela proliferação de bactérias patogênicas, causando grandes malefícios à saúde pública e ao ecossistema aquático, diminuindo cada vez mais sua disponibilidade para a espécie humana (SILVA, 2008).

Os problemas de poluição das águas são, em sua maioria, caracterizados pelo crescimento urbano, rural e industrial de forma exponencial e, em alguns ámbitos sem planejamento previo, refletindo na saúde pública. Por esse motivo, a determinação de parâmetros de avaliação e o acompanhamento da qualidade da água do manancial podem servir para fornecer elementos de comparação e monitoramento das melhorias a serem implantadas para recuperação dessa bacia (SILVA et al., 2008).

Nas últimas décadas, algumas regiões estão sofrendo escassez de água potável, perdendo o equilíbrio e ultrapassando o ponto de recuperação. Lidar com um futuro sem disponibilidade de água e com recursos hídricos escassos é agora uma possibilidade real em várias partes do mundo. A garantia de oferta de água potável para todos deve ser prioritária por se tratar de um bem vital para suprir as necessidades básicas, tornando uma preocupação aos órgãos governamentais e civil, pois a demanda por água doce em todo o mundo vem aumentado de maneira significativa (SILVA, 2014). 
Em 2012, no Brasil, cerca de 300 mil trabalhadores se afastaram das atividades por diarreias e perderam 900 mil dias de trabalho. A probabilidade de uma pessoa com acesso à rede de esgoto se ausentar as suas atividades normais por diarreia é 19,2\% menor que uma pessoa que não tem acesso à rede. Em 2013, foram notificadas mais de 340 mil internações por infecções gastrintestinais no país, 2.135 pessoas morreram em hospitais por causa das infeç̧ões gastrintestinais. Se todos tivessem saneamento básico haveria redução de 329 mortes (15,5\%).

Nos países de clima quente as diarreias ocorrem com maior frequência durante a estação chuvosa, no entanto o risco do aparecimento de doenças como cólera, giardíase, infecção por Shigella, febre tifoide, infecção por Escherichia coli, entre outras, independe da época do ano. No Brasil, as doenças de transmissão fecal-oral, especialmente as diarreias, representam em média mais de $80 \%$ das doenças relacionadas ao saneamento ambiental inadequado (IBGE, 2012).

A maioria das doenças que ocorrem em países em desenvolvimento são veiculadas pela água contaminada por micro-organismos patogênicos (COELHO et al., 2007). Entre as enfermidades relacionadas com a água, destacam-se aquelas transmitidas pela ingestão de água contaminada, denominadas portanto enfermidades de veiculação hídrica. A água é um excelente veículo de transmissão dos microrganismos, particularmente vírus, bactérias, protozoários e helmintos para humanos e animais, principalmente os de rota fecal-oral (BRASIL, 2006).

As bactérias do grupo coliformes, por habitarem normalmente o intestino de animais e humanos, servem como indicadores de contaminação fecal. Uma grande vantagem no uso de bactérias coliformes como indicadoras de contaminação fecal é sua presença em grandes quantidades nos esgotos domésticos, já que cada pessoa elimina bilhões destas bactérias diariamente. Dessa forma, havendo contaminação da água por esgotos domésticos, é grande a chance de encontrar coliformes em qualquer amostra de água (BRASIL, 2006).

Uma forma de se conhecer a qualidade da água é fazer uso do monitoramento para obter informações necessárias ao gerenciamento e ações interventivas para recuperação ou preservação dos mananciais, garantindo a sustentabilidade dos ecossistemas (LUCAS et al., 2010). O monitoramento consiste na medição ou verificação de parâmetros de qualidade e quantidade de água, que pode ser contínua ou periódica, utilizada para acompanhamento da condição e controle da qualidade do corpo de água (CONAMA, 2005).

Para monitorar a quantidade de água, faz-se necessário uso da verificação da vazão. Por vazão, entende-se o volume de água que passa numa determinada seção do rio por unidade de tempo, a qual é determinada pelas variáveis de profundidade, largura e velocidade do fluxo (CARVALHO, 2008). Sua medição é importante porque influencia na quantidade de sedimentos, na qualidade da água, nos organismos que nela vivem e seus habitats. Influenciada pelo clima e pelas estações do ano, reflete também as concentrações de oxigênio dissolvido, rios com elevada vazão apresentam uma aeração melhor e maiores teores que os rios calmos (PALHARES et al., 2007). O oxigênio dissolvido é um dos principais parâmetros para controle dos níveis 
de poluição das águas. É fundamental para manter e verificar as condições aeróbicas num curso d'água que recebe material poluidor (PEREIRA, 2004).

De grande importância na manutenção da vida aquática, na qualidade da água e devido ao seu papel fundamental para os organismos aeróbios aquáticos, pois a maioria das espécies não resistem a concentrações de oxigênio dissolvido inferiores a $4 \mathrm{mgL}^{-1}$ (PINTO et al., 2010). Um rio considerado limpo, em condições normais, apresenta normalmente, de 8 a $10 \mathrm{mgL}^{-1}$. A determinação do teor de oxigênio dissolvido é de fundamental importância na avaliação das condições de poluição por matéria orgânica em águas naturais e na detecção de impactos ambientais como eutrofização (FARIAS, 2006). Este estudo visou avaliar a qualidade sanitária da água do Rio São Manoel/MG, durante o período chuvoso, fazendo uso do acompanhamento do oxigênio dissolvido, vazão e com ênfase nos parâmetros coliformes totais e coliformes termotolerantes.

\section{MATERIAIS E MÉTODOS}

\section{Área do estudo}

O local de coleta foi na bacia hidrográfica do Rio São Manoel, afluente do Rio Pomba, subafluente do Rio Paraíba do Sul, na Serra da Mantiqueira, Zona da Mata do estado de Minas Gerais, a 70km de Juiz de Fora. Em seu percurso, passa margeando os municípios de Silveirânia e Rio Pomba, desembocando no rio Pomba. Apresenta $37 \mathrm{~km}$ de extensão, drenando uma área de $157 \mathrm{~km}^{2}$, como se pode notar na figura 1.

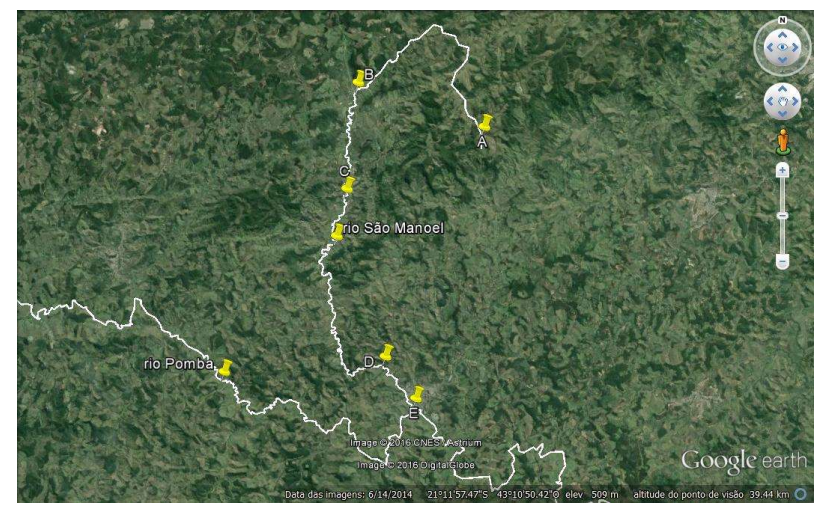

Figura 1: Pontos de coleta do Rio São Manuel (A-E).

Foram selecionados cinco pontos, conforme informações que constam na tabela 1 , que contém as coordenadas geográficas dos pontos de coleta de água no Rio São Manoel, ao longo do desse, nos municípios de Silveirânia e Rio Pomba/MG, para a coleta das amostras para analises microbiológicas, oxigênio dissolvido e vazão.

Tabela 1: Coordenadas geográficas dos pontos de coleta de água no Rio São Manoel.

\begin{tabular}{|c|c|c|c|c|c|}
\hline \multicolumn{2}{|r|}{ Pontos de coleta } & \multirow{2}{*}{$\begin{array}{c}\text { *Distância a montante } \\
0,37 \mathrm{Km} \\
\end{array}$} & \multirow{2}{*}{$\begin{array}{c}\text { Altitude } \\
805 \mathrm{~m} \\
\end{array}$} & \multicolumn{2}{|c|}{ Coordenadas geográficas } \\
\hline A & Montante & & & 21008 '19" S & $43^{\circ} 08^{\prime} 42^{\prime \prime} \mathrm{W}$ \\
\hline B & Antes da cidade de Silveirânia & $15,00 \mathrm{Km}$ & $522 \mathrm{~m}$ & $210066^{\prime} 58^{\prime \prime} \mathrm{S}$ & 43ㅇ 12' 50" W \\
\hline C & Após a cidade de Silveirânia & $21,00 \mathrm{Km}$ & $490 \mathrm{~m}$ & $21010^{\prime} 12^{\prime \prime} \mathrm{S}$ & 43 $13^{\prime} 12^{\prime \prime} \mathrm{W}$ \\
\hline $\mathrm{D}$ & Antes da cidade de Rio Pomba & $33,00 \mathrm{Km}$ & $447 \mathrm{~m}$ & $21015^{\prime} 17^{\prime \prime} \mathrm{S}$ & 43ㅇ 11' 56" W \\
\hline $\mathrm{E}$ & Jusante & $36,71 \mathrm{Km}$ & $430 \mathrm{~m}$ & $21016^{\prime} 34^{\prime \prime} \mathrm{S}$ & $43010^{\prime} 59 " \mathrm{~W}$ \\
\hline
\end{tabular}


O município de Silveirânea tem sua área urbana drenada pelo Rio São Manoel e a cidade fica na margem do rio. A cidade de Rio Pomba tem apenas cerca de um quarto da cidade drenada pelo Rio São Manoel e o mesmo passando por dentro da cidade. As duas cidades estão equidistantes a $16 \mathrm{~km}$ da via rodovia. São duas cidades de pequeno porte, com atividades econômicas semelhantes, especialmente agropecuárias, conforme os dados trazidos na tabela 2.

Tabela 2: Dados estatísticos das cidades de Rio Poma e Silveirânia em Minas Gerais.

\begin{tabular}{|c|c|c|}
\hline Item & Silveirânia & Rio Pomba \\
\hline População 2010 (habitantes) & 2.192 & 17.110 \\
\hline População estimada 2015 & 2.282 & 17.939 \\
\hline Área da unidade territorial $\left(\mathrm{km}^{2}\right)$ & 157,456 & 252,418 \\
\hline Densidade demográfica (hab/ $\mathrm{km}^{2}$ ) & 13,92 & 67,78 \\
\hline \multicolumn{3}{|l|}{ Produção Agrícola Municipal ano de 2014} \\
\hline Bovino (cabeças) & 8.671 & 15.732 \\
\hline Suíno - total (cabeças) & 2.979 & 3.471 \\
\hline Suíno - matrizes (cabeças) & 241 & 482 \\
\hline Galináceos - galinhas (cabeças) & 7.980 & 12.900 \\
\hline Vacas ordenhadas (cabeças) & 7.758 & 6.300 \\
\hline Cana-de-açúcar - Área plantada (ha) & 85 & 40 \\
\hline Cana-de-açúcar - Rendimento médio (Kg/ha) & 60.000 & 60.000 \\
\hline Banana (cacho) - Área destinada à colheita (ha) & 2 & 13 \\
\hline Banana (cacho) - Rendimento médio (Kg/ha) & 10.000 & 10.000 \\
\hline Laranja - Área destinada à colheita (ha) & 1 & 2 \\
\hline Laranja - produção (ton) & 12 & 20 \\
\hline Laranja - Rendimento médio (Kg/ha) & 12 & 10 \\
\hline
\end{tabular}

O clima de ocorrência na zona da Mata Mineira é o Tropical de Altitude, tendo distintas duas estações, uma chuvosa e outra seca, predominando a Massa Tropical Marítima e a Frente Polar Atlântica. A região onde o município de Silveirânia se situa é caracterizada por uma altura pluviométrica em torno de 1200 a $1800 \mathrm{~mm} /$ ano e a variação de temperatura apresenta média anual de $18^{\circ} \mathrm{C}$, média máxima anual de $24,4^{\circ} \mathrm{C}$ e média mínima anual de $13,8^{\circ} \mathrm{C}$, com índice pluviométrico anual de $1.436,1 \mathrm{~mm}$. A região da Zona da Mata Mineira está sujeita no período chuvoso à ocorrência do fenômeno climático denominado Zona de Convergência do Atlântico Sul - ZCAS.

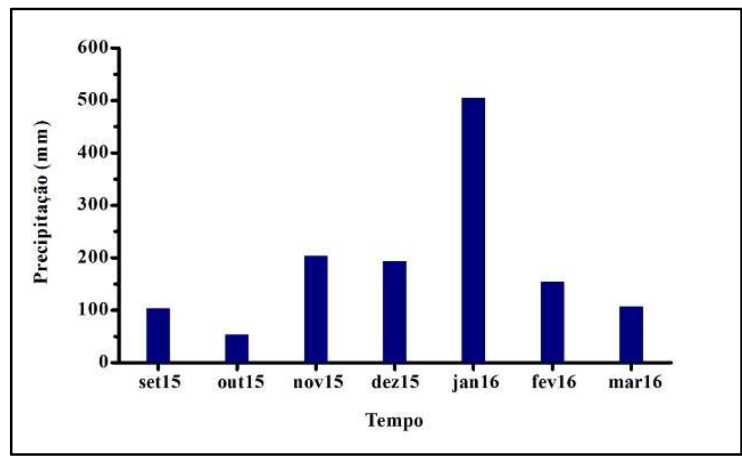

Figura 2: Precipitação na zona da mata mineira de acordo com dados fornecidos pela estação automática de Coronel Pacheco MG de Setembro 2015 a de Março 2016.

Fonte: INMET (2016).

\section{Coleta das amostras}

A sequência dos pontos de amostragem seguiu de montante para jusante, realizada preferencialmente no meio da semana no período da tarde. Com intervalo mínimo de $72 \mathrm{~h}$ após ocorrência de chuvas, como margem de segurança para evitar elevadas concentrações de bactérias que podem ser 
associados às enxurradas. As águas da chuva podem arrastar material para dentro do corpo d'água, inclusive diversas bactérias (SOUSA, 2011). As amostras de água foram coletadas em triplicata em cada ponto (ZAN et al., 2012) acondicionadas em caixa isopor e transportadas ao laboratório. Os meses de coletas foram setembro, novembro, dezembro de 2015 e janeiro, fevereiro e março de 2016.

Para realização das análises microbiológicas, as amostras de água foram processadas no dia da coleta

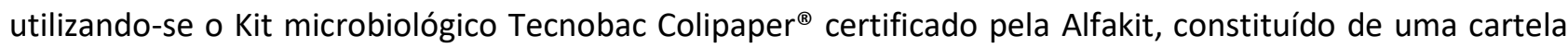
com meio de cultura em forma de gel desidratado (dipslide de papel) que detecta e quantifica a presença de coliformes fecais e totais. Emergiu-se a cartela na água diretamente do rio, aguardou-se umedecer, em seguida retirou-se a cartela e o excesso de água, finalmente, foi incubado em estufa bacteriológica por $15 \mathrm{~h}$ à temperatura de $36-37^{\circ} \mathrm{C}$. A margem de confiabilidade de detecção do teste corresponde a o mínimo de 80 UFC e a o máximo de 25.000UFC. Os valores abaixo dessa faixa foram transformados para 80UFC e os valores acima para 25.000UFC.

Posteriormente foi realizada a contagem das colônias pela distinção dos pontos de colônias com suas respectivas cores, considerando os dois lados da cartela como recomendado pelo fabricante. Sendo contados e convertidos para o número de unidades formadoras de colônias (UFC) $100 \mathrm{~mL}^{-1}$ de coliformes fecais e totais. A transformação dos dados microbiológicos para escala logarítmica e a estatística descritiva foram realizadas pelo programa BioEstat 5.3 (AYRES et al., 2007). Gráfico e a ANOVA (SILVA et al., 2014) de duas vias (Bonferroni) foram calculadas pelo GraphPad Prism ${ }^{\circledR}$ 5.0.

Para quantificar o oxigênio dissolvido disponível na água foi utilizado o oxímetro digital coletor de dados Lutron DO-5519. Dados foram obtidos no momento em que a leitura do aparelho estabilizou, variando entre 5 a 12 minutos. A vazão do rio foi medida nos mesmo pontos da amostragem da água para análise microbiológica e do oxigênio dissolvido e calculado segundo Palhares et al., (2007).

\section{RESULTADOS}

Coliformes fecais e totais foram detectados nas amostras de água do Rio São Manoel. A carga bacteriana de coliformes totais foi diferente ao longo dos pontos de coleta $(p<0,0001 ; F=319,95)$ e ao período de coleta $(p<0,0001 ; F=32,22)$. Houve interação entre os fatores ponto de coleta e tempo $(p<0,0001 ; F=6,55)$. Entre o ponto de coleta $A$ e $E$, seguindo o curso do rio de montante a jusante, a presença de coliformes totais foi superior e significativamente diferente de montante para a jusante $(p<0,001)$, de acordo com a figura 3, na qual a linha pontilhada delimita as capacidades máxima e mínima de detecção do teste. A carga bacteriana de coliformes fecais foi diferente ao longo dos pontos de coleta $(p<0,0001$; $F=398,44)$ e ao período de coleta $(p<0,0001 ; F=19,13)$. Houve interação entre os fatores ponto de coleta e tempo $(p=0,0025 ; F=2,67)$. 


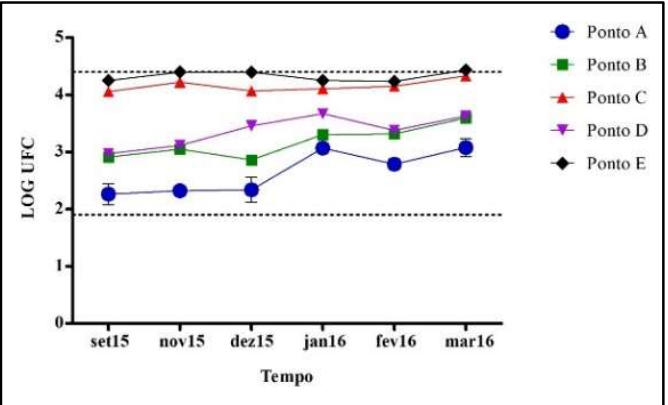

Figura 3: Gráfico de linhas que representa a carga bacteriana de coliformes totais na água do Rio São Manoel/MG, ao longo do tempo nos pontos de coleta.

Entre o ponto de coleta $A$ e $E$, seguindo o curso do rio de montante a jusante, a presença de coliformes fecais foi superior e significativamente diferente de montante para a jusante $(p<0,001)$, evidenciado na figura 4, na qual a linha pontilhada delimita a capacidade máxima e mínima de detecção do teste.

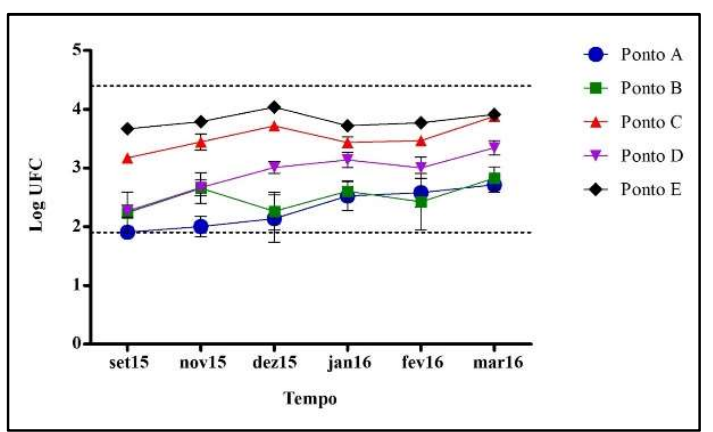

Figura 4: Gráfico de linhas que representa a carga bacteriana de coliformes fecais na água do Rio São Manoel/MG, ao longo do tempo nos pontos de coleta.

$\mathrm{Na}$ figura 5 estão apresentados os valores médios do oxigênio dissolvido, analisado por uma concentração ao longo do tempo nos pontos de coleta do Rio São Manoel/MG. Verificou-se que o valor médio foi de $6,07 \mathrm{mgL}^{-1}$, desvio padrão 0,92 para as 30 amostras. Enquanto que o valor mínimo foi de 4,0 $\mathrm{mgL}^{-1} \mathrm{e}$ máximo de $7,9 \mathrm{mgL}^{-1}$.

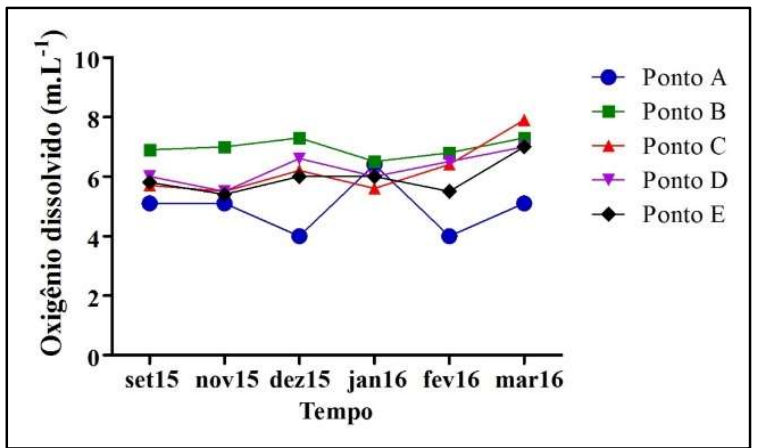

Figura 5: Concentração de oxigênio dissolvido $\left(\mathrm{mgL}^{-1}\right)$, ao longo do tempo nos pontos de coleta do Rio São Manoel/MG.

Na figura 6, os pontos de A-E apresentaram vazão crescente de montante à jusante. O mês que houve a maior vazão na maioria dos pontos foi janeiro, enquanto os meses de setembro e novembro houve as menores vazões detectadas. A unidade de medida utilizada foi L/S, no Rio São Manoel, ao longo do tempo nos pontos de coleta. Os valores de ponto foram multiplicados por 10, para melhor representação gráfica. 


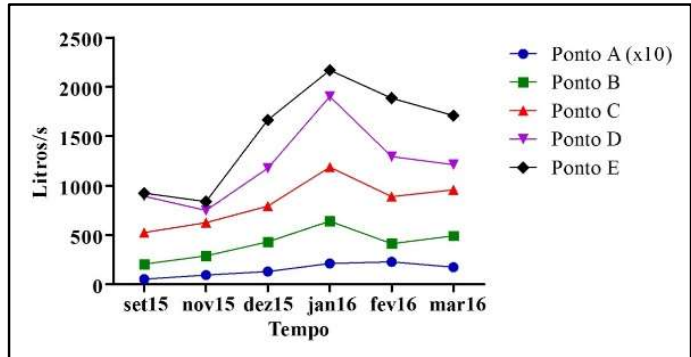

Figura 6: Vazão (L/s) do Rio São Manoel/MG, ao longo do tempo nos pontos de coleta.

\section{DISCUSSÃO}

O intervalo mínimo de $72 \mathrm{~h}$ de ocorrência de chuva no local para a coleta dos dados é imprescindível para evitar o efeito arraste. As bactérias estão presentes em grandes quantidades no solo, especialmente quando há presença de dejetos fecais. Com a ocorrência de chuva, o volume de água de escoamento superficial lava o terreno urbano e rural, carreia as bactérias para dentro do rio, o que altera transitoriamente a condição predominante do leito e contribui para a degradação da qualidade da água (ANA, 2012). A diminuição da qualidade sanitária da água é um dos fatores responsáveis pelo aumento de incidências de diarreias, especialmente no período de maior índice pluviométrico (IBGE, 2012; IBGE, 2013).

A faixa de confiabilidade do teste utilizado foi adequada tanto no estudo piloto quanto nas coletas. As 30 amostras obtidas em triplicata utilizaram 90 cartelas. Dessas 90 cartelas, 6 apresentaram resultados fora do limite de detecção confiável para coliformes fecais. Nesse caso, os valores foram transformados para o valor limite. Essa transformação implica que em alguns pontos relatados com 80UFC pode haver menor carga bacteriana detectável, assim como outros com 25.000UFC pode haver maior carga bacteriana. A montante, por exemplo, identificou-se leituras com ausência de crescimento de colônia, esses valores foram substituídos pelo valor mínimo de deteç̧ão do teste que é 80 UFC. A jusante identificou-se leituras com muitas colônias, até 41.000 , esses valores foram substituídos pelo valor máximo de confiabilidade do teste que é $25.000 U F C$.

De montante à jusante, verificou-se que houve um aumento expressivo da detecção de coliformes fecais e totais. Esse aumento coincide com a passagem do rio pelas cidades de Silveirânia e de Rio Pomba. Apesar disso existem atividades agropecuárias que ocorrem às margens do rio que também contribuíra potencialmente para a deteç̧ão de coliformes na água. Entretanto, os resultados indicam que a contribuição maior de poluição provém das cidades. Esses dois municípios não possuem tratamento de esgoto e lançam os dejetos no leito do rio.

Por outro lado, a detecção de coliformes nos pontos de amostragem após as duas cidades, foi semelhante $(p>0,05)$ e isso pode sugerir que o potencial poluidor de ambas seja semelhante, proporcionalmente ao volume de água. Embora a cidade de Rio Pomba seja maior que Silveirânia, apenas cerca de um quarto da área urbana da cidade é drenada pelo Rio São Manoel. Elas são qualitativamente equiparáveis já que margeiam o Rio São Manoel, ambas são de pequeno porte e apresentam atividades econômicas semelhantes, especialmente agropecuária. 
Foi identificada interação significativa entre os fatores tempo (mês) e localização dos pontos de coleta, tanto para coliformes totais quanto para coliformes fecais. Como a localização dos pontos de coletas foi idêntica, provavelmente as mudanças observadas que proporcionaram a interação tenham mudado ao longo do tempo. Possivelmente essa mudança com o potencial de tal magnitude tenha influencia relacionada à pluviometria, conforme se notou na figura 2 .

As menores aferições de oxigênio dissolvido foram observadas à montante, o que é condizente com a característica da área que é alagadiça. Situado na maior altitude de coleta, o local é caracterizado por acumulo de água com abundante vegetação herbácea, presença de massas orgânicas em decomposição e lentidão no escoamento das águas. Como agravante, existe atividade de pecuária de corte com acesso dos animais na área palustre para se alimentar da vegetação e saciar a sede. Todas estas características contribuem para redução do oxigênio dissolvido na água.

Os valores da vazão nos pontos foram aumentando nos primeiros meses conforme a ocorrência de precipitação. Após infiltrar na superfície do solo, parte da água das chuvas percola através das fendas, abastecendo o lençol freático, consequentemente aumenta a vazão nas nascentes. No mês de janeiro houve uma precipitação atípica superior aos demais meses e influenciou com o aumento da vazão. As informações coletadas da vazão do Rio São Manoel são compatíveis com a pluviometria da região, como se pôde verificar na figura 2. Estação meteorológica automática de Coronel Pacheco/ MG (INMET, 2016) com maior distância entre o rio e a estação de $46 \mathrm{~km}$ em linha reta (ANA, 2013).

Conforme a Portaria 518/04 do Ministério da Saúde, não é permitida a presença de coliforme fecal ou termotolerantes em $100 \mathrm{~mL}$ de água já saneada e tratada para consumo humano. A preocupação com a presença de bactérias prejudiciais à saúde humana na água vem despertando o interesse na implantação de monitoramento microbiológico, visando diagnosticar os problemas, suas dimensões e os riscos para a saúde humana e animal. O monitoramento e identificação dos pontos de contaminação fornecerá uma base de dados com importante impacto socioeconômico podendo ser utilizada para tomadas de decisões e formulação de novas políticas ambientais.

O rio está poluído. Portanto, de acordo com a Resolução 357/2005 do Conselho Nacional do Meio Ambiente (CONAMA, 2005), a água do Rio São Manoel é inapropriada ao consumo humano e animal, o seu uso direto não é indicado para à recreação de contato primário e secundário, à irrigação de hortaliças que são consumidas cruas e de frutas que se desenvolvam rentes ao solo e que sejam ingeridas cruas sem remoção de película, à irrigação de parques, jardins, campos de esporte e lazer, com os quais o público possa ter contato direto, à aquicultura e à atividade de pesca, à dessedentação de animais. Dessa maneira, medidas de saneamento básico são recomendadas para reduzir a proliferação de doenças veiculadas pela água, preservar a qualidade do ambiente e a sobrevivência dos seres dependentes do mesmo.

\section{CONCLUSÕES}

A água do Rio São Manoel está poluída e imprópia ao consumo humano e animal. Coliformes totais e fecais foram detectados ao longo do rio. Esta contaminação é característica de dejetos não tratados 
despejados no leito. Foi comprovada interação da mudança de carga bacteriana nos pontos de coletas ao longo do tempo. Recomenda-se aplicar medidas de saneamento básico com tratamento do afluente de acordo com a legislação.

\section{REFERÊNCIAS}

ANA. Agência Nacional de Águas. Água na medida certa: a hidrometria no Brasil. Brasília: ANA, 2012.

ANA. Agência Nacional de Águas. Conjuntura dos recursos hídricos no Brasil. Brasília: ANA, 2013

AYRES, M.; AYRES, M. J.; AYRES, D. L.; SANTOS, A. D. A. S. BioEstat 5.0: aplicações estatísticas nas áreas da ciências biológicas e médicas. Belém: UFPA, 2007.

BRASIL. Ministério da Saúde. Vigilância e controle da qualidade da água para consumo humano. Brasília: Ministério da Saúde, 2006.

CARVALHO, T. M. Técnicas de medição de vazão por meios convencionais e não convencionais. Revista Brasileira de Geografia Física, Recife, v.1, n.1, p.73-85 2008.

COELHO, D. A.. Avaliação da qualidade microbiológica de águas minerais comercializadas em supermercados da cidade de Alfenas (MG). Revista Higiene Alimentar, São Paulo, v.21, n.154, p.93-98, 2007.

CONAMA. Conselho Nacional do Meio Ambiente. Resolução CONAMA n.357 de 17 de março de 2005. Brasília: CONAMA 2005.

FARIAS, M. S. S.. Monitoramento da qualidade da água na Bacia Hidrográfica do Rio Cabelo. Tese (Doutorado) Universidade Federal de Campina Grande, Campina Grande, 2006.

IBGE. Instituto Brasileiro de Geografia e Estatística. Cidadania, Indicadores Sociais: um terço dos brasileiros não têm acesso simultâneo a saneamento e luz. Rio de Janeiro: IBGE, 2013.

IBGE. Instituto Brasileiro de Geografia e Estatística. Indicadores de Desenvolvimento Sustentável: Brasil 2012. Rio de Janeiro: IBGE, 2012.

INMET. Instituto Nacional de Meteorologia. Consulta Dados da Estação Automática. Coronel Pacheco: INMET 2016.

LUCAS, A. A. T.; FOLEGATTI, M. V.; DUARTE, S. N.. Qualidade da água em uma microbacia hidrográfica do Rio Piracicaba, SP. Revista Brasileira de Engenharia Agrícola e Ambiental, v.14, n.9, p.937-943, 2010.

PALHARES, J. C. P.; RAMOS, C.; KLEIN, J. B.; LIMA, J. M. M.; MULLER, S.; CESTONARO, T.. Medição da Vazão em Rios pelo Método do Flutuador. Concórdia: EMBRAPA, 2007.
PARADELA, A. L.; HUSSAR, G. J.; ALMEIDA, R. M. A.; ROMÃO, A. P.; GONÇALVES, R. H.; MIYAMOTO, L.. Ação de compostos na descontaminação de beterraba com bactérias do grupo coliformes. Engenharia Ambiental, Espírito Santo do Pinhal, v.3, n.1, p.42-51, 2006.

PEREIRA, R. S.. Identificação e caracterização das fontes de poluição em sistemas hídricos. Revista Eletrônica de Recursos Hídricos, Porto Alegre, v.1, n.1, p. 20-36, 2004.

PINTO, A, L.; OLIVEIRA, G. H.; PEREIRA, G. A.. Avaliação da eficiência da utilização do oxigênio dissolvido como principal indicador da qualidade das águas superficiais da bacia do Córrego Bom Jardim, Brasilândias/MS. Revista Geomae, v.1, n.1, p.69-82, 2010.

SILVA, A. B. A.; UENO, M.. Qualidade sanitária das águas do Rio Una, São Paulo, Brasil, no período das chuvas. Revista Biociências, Taubaté, v.14, n.1, p.36-42, 2008

SILVA, E. S.; OLIVEIRA, J. C.. Avaliação da qualidade da água da Reserva Particular do Patrimônio Natural (RPPN) Seringal Triunfo, Rio Araguari, Ferreira Gomes - AP - Brasil. Biota Amazônia, Macapá, v.4, n.2, p.28-42, 2014

SILVA, R. R.. Bacia do rio Pomba (MG) [Manuscrito]: uso e ocupação do solo e impactos ambientais nos recursos hídricos. Goiânia: UFG, 2014.

SILVA, S. M.; CARVALHO, L.; QUEROL, E.; QUEROL, M. V.; GONÇALVES, J. F.. Análise microbiológica no Arroio Salso de cima e rio Uruguai. Biodiversidade Pampeana, Uruguaiana, v.6, n.1, p.34-39, 2008

SILVEIRA, T.. Análise físico-química da água da Bacia do Rio Cabelo - João Pessoa-PB. In: CONGRESSO DE PESQUISA E INOVAÇÃO DA REDE NORTE NORDESTE DE EDUCAÇÃO TECNOLÓGICA JOÃO PESSOA, 2. Anais. João Pessoa: 2007.

SOUSA, F. D. M.; GIRÃO, E. G.; GOMES, R. B.; SISTE, C. E.. Protocolo de garantia de qualidade dos dados do monitoramento bacteriológico. Fortaleza: Embrapa Agroindústria Tropical, 2011.

TUCCI, C. E. M.. Águas urbanas. Estudos avançados, v.22, n.63, p.1-16, 2008.

ZAN, R. A.; COSTA, A. L.; COSTA, J. B.; MENEGUETTI, D. U. O. Análise microbiológica de amostras de água de poços rasos localizados no município de Buritis, região do vale do Jamari, Rondônia, Amazônia Ocidental. Educação Ambiental, v.8, n.8, p.1867-1875, 2012. 